\title{
Students' Statements on Utilization of Learning Media during Online Learning in the Covid-19 Pandemic in Indonesia
}

\author{
Novi Trisnawati, Triesninda Pahlevi, Brillian Rosy, Lifa Farida Panduwinata, \\ Febrika Yogie Hermanto
}

Universitas Negeri Surabaya, Faculty of Economics and Business, Surabaya, Indonesia

\begin{abstract}
The purpose of this study is to reveal students' perspective of the online learning media during the Covid-19 pandemic. This study is conducted in the University Negeri Surabaya with 118 respondents. A questioner used a Likert scale that can reflect the students' perception on difficulties of media, attractiveness of media, convenience of media, easiness of material understanding, and satisfaction of media. This study shows that the tendency of lecturers to carry out online learning in the Covid-19 pandemic era is achieved through assignments and online meetings. Also, students' assessments of online learning media used in this study fall into the good category, so the chosen online learning media are suitable for use in learning. This study implies that learning media combination is needed during the Covid-19 pandemic since not every student can effectively learn by the online system.
\end{abstract}

Keywords - Learning Media, Online Learning, Covid-19 Pandemic.

\section{Introduction}

The Covid-19 pandemic has made many changes in the education aspect of many countries in the world.

DOI: $10.18421 /$ SAR43-05

https://doi.org/10.18421/SAR43-05

Corresponding author: Novi Trisnawati,

Faculty of Economics and Business, Universitas Negeri

Surabaya, Indonesia.

Email: novitrisnawati@unesa.ac.id

Received: 11 June 2021.

Revised: 04 September 2021.

Accepted: 09 September 2021.

Published: 23 September 2021.

(c) (1) (5) 2021 Novi Trisnawati et al; published by UIKTEN. This work is licensed under the CCBY-NC 4.0.

The article is published with Open Access at www.sarjournal.com
The level of its spread and transmission has made almost all governments adopt policies to implement social restrictions [1], both large and small scale. Then, this restriction policy results in learning to be done with online learning, where education changes rapidly by taking advantage of technological developments. Meanwhile, online learning has never been fully conducted by all levels of Indonesia's education.

Online learning of universities emerged as one of the alternative learning methods that can be carried out during the Covid-19 pandemic, where they do not have to be present in class to have face-to-face meetings with lecturers [2]. Online learning has the advantage of shaping students' learning independence and encouraging students' enthusiasm for learning. [3] stated that online learning can be fun learning because students can listen to learning materials via smartphones, laptops, or computers, so they can actively search for provided information on the internet, both learning materials provided by lecturers and other learning material sources. This learning is expected to help lecturers in carrying out learning of the pandemic era.

On the other hand, [4] states that online learning also has an impact on students, namely 1) the health impact of using computers or smartphones for too long, 2) the presence of electromagnetic radiation, network addicts, anti-social, low of the logical students' abilities due to multi-medialization of learning materials, and 3) lack of students' interest in the direct learning. [5] adds that online learning has an impact on students who obtain the ease of learning, anytime and anywhere, and they can learn independently, and the student interactions will be reduced, so they are less competent and less responsive in their social environment.

According to [6] not all learning can be conducted by using online media, such as practical learning which requires direct learning, face-to-face learning. Online learning can be conducted if the learning media can support the required learning. [7] states that the purpose of learning media is to facilitate 
learning by teachers or lectures. The used learning media have gone through an evaluation process so the media can be declared that is suitable for learning. The suitable learning media is learning media that have passed the evaluation aspects of 1) Difficulties, 2) Attractiveness, 3) Convenience, 4) Easiness and 5) Satisfaction [8].

The use of online learning media during the Covid19 pandemic at the University Negeri Surabaya (Unesa) was mostly carried out with online learning media, both the learning media platform owned by Unesa, Vinesa (Vilearning Unesa), and the other learning media platforms. The purpose of this study is to reveal the students' perceptions of the online learning media during the Covid-19 pandemic in Unesa. Also, this study was used to explore students' perceptions of online learning needs, so this study can be used as a reference in building an online learning media platform that suits the needs of the Unesa.

\section{Method}

This study is a descriptive study with a mixedmethod approach, quantitative and qualitative methods. The quantitative method is used to assess online learning media used at the University Negeri Surabaya. The qualitative method is used to reveal problems faced by online learning media, and to analyze the potential of online learning media used so the learning can be carried out effectively to respond to the Covid-19 pandemic.

Data collection of this study was carried out using questionnaires that are used to measure difficulties, attractiveness, convenience, easiness of material understanding, and satisfaction of media. This research was conducted at the University Negeri Surabaya to 118 students consisting of three generations, namely grades of 2017, 2018, and 2019. This research was conducted on students who conducted online learning, in the Covid-19 Pandemic, who used learning media in the form of Google Classroom, Google Meet, Zoom, Vinesa, and WhatsApp Group. Data collection was carried out by using a cross-sectional survey, where [9] this research is expected to describe the attitudes, behaviors, and characteristics of the population obtained through a sample in the population.

Besides, data collection in this study was carried out by interview, where the data was used to dig deeper regarding the experienced problems by students in the use of online learning media. This data is expected to support the quantitative data so the findings can be explored more deeply.

\section{Data Analysis}

Data analysis is conducted by using quantitative and qualitative analysis, in which quantitative analysis uses the categories in the five-scale scoring guideline, and the aim is to describe the obtained data based on the survey of the studied indicators in assessing the use of online learning media. Quantitative analysis is conducted by calculating a score with a formula that can be used to describe assessments of online learning media that are used by students, which according to [7] are as follows:

Table 1. Five-Scale Scoring Guidelines

\begin{tabular}{|c|c|c|c|}
\hline Score & Formulation & Range & Classification \\
\hline 5 & $\mathrm{X}_{\mathrm{i}}+0,6 \mathrm{SB}_{\mathrm{i}}<\mathrm{X}$ & $4,21-5,00$ & Very Good \\
\hline 4 & $\mathrm{X}_{\mathrm{i}}+0,6 \mathrm{SB}_{\mathrm{i}}<\mathrm{X}<\mathrm{X}_{\mathrm{i}}+1,8 \mathrm{SB}_{\mathrm{i}}$ & $3,41-4,20$ & Good \\
\hline 3 & $\mathrm{X}_{\mathrm{i}}-0,6 \mathrm{SB}_{\mathrm{i}}<\mathrm{X}<\mathrm{X}_{\mathrm{i}}+0,6 \mathrm{SB}_{\mathrm{i}}$ & $2,61-3,40$ & Enough \\
\hline 2 & $\mathrm{X}_{\mathrm{i}}-1,8 \mathrm{SB}_{\mathrm{i}}<\mathrm{X}<\mathrm{X}_{\mathrm{i}}-0,6 \mathrm{SB}_{\mathrm{i}}$ & $1,81-2,60$ & Not Good \\
\hline 1 & $\mathrm{X}<\mathrm{X}_{\mathrm{i}}-1,8 \mathrm{SB}_{\mathrm{i}}$ & $0-1,80$ & Very Not Good \\
\hline
\end{tabular}

Based on the table, researchers can assess what category the learning media used in online learning at University Negeri Surabaya fall into what category. To get the score from the scale, we have to know that $\mathrm{X}$ is the obtained score, and $\mathrm{Xi}$ is the average-ideal score, where the score is obtained from:

$$
\mathrm{Xi}=1 / 2
$$

$$
\text { (ideal maximum score }+ \text { ideal minimum score) }
$$

Then, SBi is the standard deviation of the ideal score, where the standard deviation is obtained as follows:

$$
\begin{gathered}
\mathrm{SBi}=\frac{1}{6} \\
\text { (ideal maximum score }+ \text { ideal minimum score) }
\end{gathered}
$$

Also, qualitative analysis was performed by using Miles and Huberman's models, and the data are presented in a matrix, so the data can be easily understood by readers (Miles \& Hubberman, 1994). The data is expected to explore the problems of using online learning media so the online learning can be conducted effectively.

\section{Results}

This study was built to reveal students' perceptions on the use of online learning media that is used in the University Negeri Surabaya (Unesa), Indonesia, during the Covid-19 pandemic. The findings indicate 
that the learning media that is used most frequently by lecturers in online learning is Google Classroom with a $34 \%$ score. More details for the percentage of other learning media that are often used by lecturers are Google Meet 32\%, WhatsApp Group 25\%, Vilearning of Unesa 7\%, and Zoom 2\%. The selection of Google Classroom is based on ease of use, and more efficient internet quota usage.
Therefore, lecturers and students prefer to use Google Classroom in learning.

Also, the results are related to the assessment of the learning media in which it was divided into five indicators, namely: 1) Difficulties of Media, 2) Attractiveness of Media, 3) Convenience of Media, 4) Easiness of Material Understanding, 5) Satisfaction of Media, as follows:

Table 2. Student Assessment of Online Learning Media

\begin{tabular}{|c|c|c|c|c|c|}
\hline Grade & $\begin{array}{c}\text { Difficulties of } \\
\text { Media }\end{array}$ & $\begin{array}{c}\text { Attractiveness } \\
\text { of Media }\end{array}$ & $\begin{array}{c}\text { Convenience } \\
\text { of Media }\end{array}$ & $\begin{array}{c}\text { Easiness of } \\
\text { Material } \\
\text { Understanding }\end{array}$ & $\begin{array}{c}\text { Satisfaction of } \\
\text { Media }\end{array}$ \\
\hline 2017 & 3.78 & 3.98 & 3.87 & 3.51 & 3.71 \\
\hline 2018 & 3.87 & 4.02 & 3.91 & 3.42 & 3.65 \\
\hline 2019 & 3.73 & 3.86 & 3.91 & 3.40 & 3.63 \\
\hline All Students & $\mathbf{3 . 7 9}$ & $\mathbf{3 . 9 5}$ & $\mathbf{3 . 8 9}$ & $\mathbf{3 . 4 4}$ & $\mathbf{3 . 6 6}$ \\
\hline
\end{tabular}

The score shows that the online learning media that is used by students falls into good criteria. The tendency of the obtained assessments in each grade shows that only the indicator for the level of Easiness of Material Understanding, in class 2019, gets 3.40 score where the score falls into enough category. Meanwhile, the assessment of all students on the Indicator of Easiness of Material Understanding gets a score of 3.44, where this score was still in the good category. This phenomenon needs to be explored more deeply, which is why this indicator got the lowest score. On the other hand, the highest score in the conducted survey was in the indicator for attractiveness of media in which the score is 3.95, and the class of 2018 got the highest score of 4.02.
On the other hand, according to students' perceptions, virtual meeting media, Google Meet, is the most favourite online learning media that is used for learning during the Covid-19 pandemic, nowadays. This view is based on the disclosure that is made by researchers through the recapitulation of data in using online learning media. The recapitulation shows that the use of Google Meet learning media gets $37 \%$, Google Classroom gets $28 \%$, Whatsapp Group gets $23 \%$, Zoom gets $11 \%$, and Vilearning of Unesa $1 \%$. Also, the choice of online learning media is made by students that are greatly influenced by the effectiveness of learning and the ease of accessing the media. That data is supported by the interviews data that was conducted by researchers, as follows:

Table 3. Data Matrix of Problems of Online Learning

\begin{tabular}{|l|c|c|}
\hline \multicolumn{1}{|c|}{ Problems } & Cases & Factors \\
\hline Signal interference & \multirow{2}{*}{ Internet Acces } & \multirow{2}{*}{ Economy } \\
\cline { 1 - 1 } Limited internet quota & \multirow{2}{*}{ Learning Tool } & \\
\cline { 1 - 1 } Too close deadline of the assignments & & \multirow{2}{*}{ Learning } \\
\cline { 1 - 1 } Monotone Online Learning & & \\
\cline { 1 - 1 } Vilearning of Unesa error & & \\
\cline { 1 - 1 } Less interactive learning media & & \\
\cline { 1 - 1 } Learning materials are not accessible & & \\
\cline { 1 - 1 } The use of limited learning media & & \\
\cline { 1 - 1 } Not all lectures conducted by active learning & & \\
\hline
\end{tabular}

Based on that data, the researcher saw that the problems of online learning were classified into two problems, namely economic problems and learning problems. Both of these problems, in detail, are caused by internet access, the used learning tools, and the used learning model. This problem causes the learning that is not carried out effectively by students so it needs to be improvements and adjustments in the use of learning media according to their learning needs.

\section{Discussion}

During the Covid-19 pandemic, online learning often encountered obstacles, such as: making acceptable learning media for all students and 
making assessments according to the learning [10]. This situation is complicated by the number of infected people with Covid-19 so the pandemic period is not over, yet. [11], [12] stated that the situation of the pandemic will get worse if there are no social restrictions, so learning at university has to be arranged in an online system. Meanwhile, online learning still needs to be adjusted [13], so it can be carried out effectively by university students.

The results of the study show that the lecturers at the Unesa mostly use Google Classroom learning media with a percentage of $34 \%$. Also, the second most widely used online learning media is Google Meet learning media with a percentage of $32 \%$. With the existence of two online learning media that are often used by lecturers, it shows that the propensity of lecturers to choose online learning media can be used for assignments and virtual meetings. Both Google Classroom and Google Meet learning media are favorite learning media that are used by lecturers at the Unesa.

Student assessments related to online learning media show that online learning media get good ratings on all the indicators studied, namely 1) Difficulties of Media, 2) Attractiveness of Media, 3) Convenience of Media, 4) Easiness of Material Understanding, 5) Satisfaction of Media. This assessment shows that the aspects that are in the online learning media used indicate that they are suitable for learning.

Slightly different from the propensity of lecturers to choose online learning media in learning, students tend to prefer to use learning media in virtual meetings media. This propensity can be observed in the selection of online learning media by students, where Google Meet is the most popular learning media with a percentage of $37 \%$. Then, in assignments, students prefer to use learning media that makes it easier for them to send predetermined assignments, where Google Classroom learning media is the second favorite learning media with a percentage of $28 \%$. The data also shows that the trend of learning carried out by lecturers at the Unesa is to use virtual meetings and assignments.

On the other hand, the selection of online learning media that was carried out also encountered problems that were mainly experienced by students. Based on the results of the interviews conducted, the main problem in online learning is internet access, where many students are constrained by internet access if they want to do learning with virtual meetings. This problem tends to occur to students who have a low economy. As a result of these problems, learning cannot be carried out effectively for all students who should get the same portion of learning. Also, the learning media and learning models that are carried out cannot reach all students because each student faces different problems. The aspects that need to be considered in choosing this online learning media are 1) attractiveness, 2) ease of access, 3) ease of use and 4) compatibility for virtual meetings. If learning cannot be effectively conducted with one online learning media, then we need to combine the learning media used in each lesson [13]. The use of combination learning media is dedicated to facilitating students who experience problems in online learning.

\section{Implication for Management}

Our study implies that the propensity of Unesa students and lecturers in choosing online learning media prefer to use attractive learning media, easyto-access learning media, fluency in using learning media, and learning media can be used for virtual meetings. These findings can be used by relevant stakeholders to build a learning media platform that can cover the needs of students and lecturers in conducting online learning, especially in the current Covid-19 pandemic era. This finding is also supported by the results of student's and lecturer's assessments of online learning media that is built by Unesa, Vinesa (Vilearning of Unesa), which received small scores and were not even chosen by students. This case indicates that there are still problems that occur in the Vinesa learning media platform. Also, in the interview results, it was stated that the use of Vinesa still often experienced obstacles or application errors.

Although it is difficult to build, Unesa needs to improve its online learning media platform, Vinesa, by considering the needs for online learning in the University, because online learning media, in the Covid-19 Pandemic, is considered more effective for theoretical learning [14], [15]. Besides, the future universities have to provide the innovation of learning facilities based on Big Data and IoT to be smart universities, and the teaching can be carried out flexibly by lecturers to students without limited space and time.

\section{Conclusion}

This research shows that the propensity of lecturers to do learning in the Covid-19 pandemic is achieved by assignments and virtual meetings. Students' assessments of online learning media used in this study fall into the good category, where the assessment indicates that the chosen online learning media is suitable for learning. The online learning media that students are most interested in is virtual meeting learning media by using Google Meeting. Moreover, almost all students can participate in online learning with virtual meeting learning media 
smoothly because some students experience problems with their internet access. Thus, online learning in the era of the Covid-19 pandemic should use a combination of online learning media that can include the need to explain the material, virtual meetings, and the need to collect simple and accessible assignments.

The findings in this study indicate that Vinesa (Virtual Learning of Unesa) needs to be adjusted to the needs of online learning such as 1) using attractive learning media, 2) easy-to-access learning media, 3) fluency in using learning media, and 4) learning media, which can be used used for virtual meetings. Besides, lecturers need to provide an understanding of digital literacy, and train students related to independent learning, reliability in finding information, and the ability to use technology so they can respond to online learning problems well. Further research needs to be done on a wider scale, and with different research methods, so it can dig deeper problems of online learning.

\section{References}

[1]. Khachfe, H. H., Chahrour, M., Sammouri, J., Salhab, H., Makki, B. E., \& Fares, M. (2020). An epidemiological study on COVID-19: a rapidly spreading disease. Cureus, 12(3).

[2]. Zhafira, N. H., Ertika, Y., \& Chairiyaton, C. (2020). Persepsi mahasiswa terhadap perkuliahan daring sebagai sarana pembelajaran. Jurnal Bisnis Dan Kajian Strategi Manajemen, 4(1).

[3]. Sobron, A. N., \& Bayu, R. (2019). Persepsi siswa dalam studi pengaruh daring learning terhadap minat belajar ipa. SCAFFOLDING: Jurnal Pendidikan Islam Dan Multikulturalisme, 1(2), 30-38.

[4]. Nazarlou, M. M. (2013). Research on negative effect on e-learning. International Journal of Mobile Network Communications \& Telematics (IJMNCT) Vol, 3.

[5]. Dunlosky, J., Rawson, K. A., Marsh, E. J., Nathan, M. J., \& Willingham, D. T. (2013). Improving students' learning with effective learning techniques: Promising directions from cognitive and educational psychology. Psychological Science in the Public Interest, 14(1), 4-58.
[6]. Önöral, Ö., \& Kurtulmus-Yilmaz, S. (2020). Influence of covid-19 pandemic on dental education in Cyprus: Preclinical and clinical implications with e-learning strategies. Advanced Education, 7(16), 69-77.

[7]. Saputri, A., Sukirno, S., Kurniawan, H., \& Probowasito, T. (2020). Developing Android GameBased Learning Media "Go Accounting" in Accounting Learning. Indonesian Journal on Learning and Advanced Education (IJOLAE), 2(2), 91-99.

[8]. Paseleng, M. C., \& Arfiyani, R. (2015). Pengimplementasian media pembelajaran berbasis multimedia interaktif pada mata pelajaran matematika di sekolah dasar. Scholaria: Jurnal Pendidikan Dan Kebudayaan, 5(2), 131-149.

[9]. Creswell, J. W. (2012). Educational researchplanning, conducting, and evaluating quantitative and qualitative research . Boston, MA: Pearsons Education. Inc. doi, 10.

[10]. Arlinwibowo, J., Retnawati, H., Kartowagiran, B., \& Kassymova, G. K. (2020). Distance learning policy in Indonesia for facing pandemic COVID-19: School reaction and lesson plans. Journal of Theoretical and Applied Information Technology, 2828-2838.

[11]. Jackson, C., Vynnycky, E., Hawker, J., Olowokure, B., \& Mangtani, P. (2013). School closures and influenza: systematic review of epidemiological studies. BMJ open, 3(2), e002149.

[12]. Jackson, M. L., Hart, G. R., McCulloch, D. J., Adler, A., Brandstetter, E., Fay, K., ... \& Seattle Flu Study Investigators. (2020). Effects of weather-related social distancing on city-scale transmission of respiratory viruses. medRxiv.

[13]. Ranu, E. (2021). The Effectiveness of Distance Practice Learning For Facing Covid-19 Pandemic In Indonesia. Journal of Theoretical and Applied Information Technology, 99(12).

[14]. Moazami, F., Bahrampour, E., Azar, M. R., Jahedi, F., \& Moattari, M. (2014). Comparing two methods of education (virtual versus traditional) on learning of Iranian dental students: a post-test only design study. BMC medical education, 14(1), 1-5.

[15]. Bevz, V., \& Dmytriienko, O. (2020). Students' Perceptions of the History of Science and Technology Course at Teacher Training University. Advanced Education, 15, 74-80. 